\title{
Impact of $\mathrm{Na}^{+} / \mathrm{Ca}^{2+}$ Exchangers on Therapy Resistance of Ovary Carcinoma Cells
}

\author{
Lisann Pelzl ${ }^{a}$ Zohreh Hosseinzadeha ${ }^{a}$ Kousi Alzoubia Tamer Al-Maghout ${ }^{a}$ \\ Sebastian Schmidt ${ }^{\mathrm{a}}$ Christos Stournaras ${ }^{\mathrm{a}, \mathrm{c}}$ Florian Lang ${ }^{\mathrm{a}}$ \\ ${ }^{a}$ Department of Physiology, ${ }^{b}$ Experimental Retinal Prosthetics Group, Institute for Ophthalmic Research, \\ University of Tübingen, Tübingen, Germany; 'University of Crete Medical School, Department of \\ Biochemistry, Voutes, Heraklion, Greece
}

\section{Key Words}

NCX3 $・$ NCKX4 $・$ NCKX5 $・$ NCKX6 $•$ Cisplatin $・$ Apoptosis

\begin{abstract}
Background/Aims: According to previous observations, enhanced store-operated $\mathrm{Ca}^{2+}$-entry (SOCE) accomplished by the pore forming ion channel unit Orai1 and its regulator STIM1 contribute to therapy resistance of ovary carcinoma cells. $\mathrm{Ca}^{2+}$ signaling is further shaped by $\mathrm{Ca}^{2+}$ extrusion through $\mathrm{K}^{+}$-independent $(\mathrm{NCX})$ and/or $\mathrm{K}^{+}$-dependent $(\mathrm{NCKX}) \mathrm{Na}^{+} / \mathrm{Ca}^{2+}$ exchangers. The present study thus explored whether therapy resistance is further paralleled by altered expression and/or function of $\mathrm{Na}^{+} / \mathrm{Ca}^{2+}$-exchangers. Methods: In therapy resistant (A2780cis) and therapy sensitive (A2780sens) ovary carcinoma cells transcript levels were estimated from RT-PCR, cytosolic $\mathrm{Ca}^{2+}$-activity $\left(\left[\mathrm{Ca}^{2+}\right]_{\text {; }}\right)$ from Fura-2-fluorescence, $\mathrm{Na}^{+} / \mathrm{Ca}^{2+}-$ exchanger activity from the increase of $\left[\mathrm{Ca}^{2+}\right]_{\mathrm{i}}\left(\Delta\left[\mathrm{Ca}^{2+}\right]_{\mathrm{i}}\right)$ and from whole cell current $\left(\mathrm{I}_{\mathrm{ca}}\right)$ following abrupt replacement of $\mathrm{Na}^{+}$containing $(130 \mathrm{mM})$ and $\mathrm{Ca}^{2+}$ free extracellular perfusate by $\mathrm{Na}^{+}$free and $\mathrm{Ca}^{2+}$ containing $(2 \mathrm{mM})$ extracellular perfusate, as well as cell death from PI -staining in flow cytometry. Results: The transcript levels of NCX3, NCKX4, NCKX5, and NCKX6, slope and peak of $\Delta\left[\mathrm{Ca}^{2+}\right]_{i}$ as well as $I_{\text {ca }}$ were significantly higher in therapy resistant than in therapy sensitive ovary carcinoma cells. The $\mathrm{Na}^{+} / \mathrm{Ca}^{2+}$-exchanger inhibitor KB-R7943 (10 $\left.\mu \mathrm{M}\right)$ significantly blunted $\Delta\left[\mathrm{Ca}^{2+}\right]_{i}$ and significantly augmented the cisplatin-induced cell death of therapy resistant ovary carcinoma cells without significantly modifying cisplatin-induced cell death of therapy sensitive ovary carcinoma cells. Conclusion: Enhanced $\mathrm{Na}^{+} / \mathrm{Ca}^{2+}$-exchanger activity may contribute to the therapy sensitivity of ovary carcinoma cells.
\end{abstract}

Prof. Dr. Florian Lang

KARGER 125
Physiologisches Institut, der Universität Tübingen

Gmelinstr. 5, D-72076 Tübingen (Germany)

Tel. +49 707129 72194, Fax. +49 707129 5618, E-Mail florian.lang@uni-tuebingen.de 


\section{Cellular Physiology Cell Physiol Biochem 2015;37:1857-1868

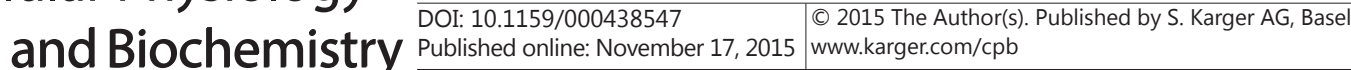 \\ Pelzl et al.: $\mathrm{Na}^{+} / \mathrm{Ca}^{2+}$ Exchangers in Therapy Resistant Ovary Carcinoma Cells}

\section{Introduction}

Alterations of cytosolic $\mathrm{Ca}^{2+}$ activity contribute to the regulation of diverse cellular mechanisms, such as excitation, exocytosis, migration, cell proliferation and cell death [15]. Cytosolic $\mathrm{Ca}^{2+}$ concentration $\left(\left[\mathrm{Ca}^{2+}\right]_{\mathrm{i}}\right)$ is increased by several mechanisms including $\mathrm{Ca}^{2+}$ release from intracellular stores with subsequent triggering of store operated $\mathrm{Ca}^{2+}$ entry (SOCE) accomplished by Orai [6-10] and STIM [11-15] isoforms. Orai1 and STIM1 are expressed in and contribute to the survival of several tumor cells [16-20] including therapy resistant ovary carcinoma cells [21].

Cytosolic $\mathrm{Ca}^{2+}$ activity is further modified by $\mathrm{Ca}^{2+}$ extrusion accomplished by several mechanisms including $\mathrm{Na}^{+} / \mathrm{Ca}^{2+}$ exchangers, which thus contribute to the shaping of duration, amplitude and intracellular location of $\mathrm{Ca}^{2+}$ signals [22-24]. $\mathrm{Na}^{+} / \mathrm{Ca}^{2+}$ exchangers operate with far higher turnover rates than $\mathrm{Ca}^{2+}$ ATPases [25]. Six $\mathrm{K}^{+}$-dependent (NCKX) and three $\mathrm{K}^{+}$-independent (NCX) $\mathrm{Na}^{+} / \mathrm{Ca}^{2+}$ exchanger isoforms have been identified [26-28]. NCX isoforms exchange three $\mathrm{Na}^{+}$ions for one $\mathrm{Ca}^{2+}$ ion and NCKX isoforms exchange one $\mathrm{K}^{+}$ion and one $\mathrm{Ca}^{2+}$ ion for four $\mathrm{Na}^{+}$ions [29]. The direction of transport by $\mathrm{Na}^{+} / \mathrm{Ca}^{2+}$ exchangers depends on the electrochemical driving forces, i.e. the cell membrane potential, the $\mathrm{Na}^{+}$ gradient and the $\mathrm{Ca}^{2+}$ gradient [30].

The present study explored whether ovary carcinoma cells express $\mathrm{Na}^{+} / \mathrm{Ca}^{2+}$ exchangers and whether $\mathrm{Na}^{+} / \mathrm{Ca}^{2+}$ exchanger expression and function differs between therapy resistant and therapy sensitive ovary carcinoma cells. To this end, the transcript levels of the three NCX and six NCKX isoforms were quantified, $\mathrm{Na}^{+} / \mathrm{Ca}^{2+}$ exchanger activity determined and the impact of NCX inhibition on cisplatin induced cell death analyzed.

\section{Materials and Methods}

\section{Ethics Statement}

Investigation has been conducted in accordance with the ethical standards and according to the Declaration of Helsinki and according to national and international guidelines and has been approved by the authors' institutional review board.

\section{Cell culture}

Experiments were performed in cisplatin-resistant cells (A2780cis) and their therapy sensitive parent cells (A2780sens) (ECACC catalogue no. 93112519). A2780cis has been generated by exposure to increasing concentrations of cisplatin and is further resistant to melphalan, adriamycin and irradiation [3133]. The cells were cultured in Dulbecco's RPMI media, containing $10 \%$ fetal calf serum and $1 \%$ antibiotic/ antimycotic solution. Where indicated, the cells were treated with cisplatin (100 $\mu \mathrm{M})$ (Sigma, Taufkirchen, Germany) [21] or the NCX inhibitor [34] KB-R7943 (10 $\mu \mathrm{M})$ (Sigma, Taufkirchen, Germany).

\section{Real-time PCR}

Total RNA was extracted from ovary carcinoma cells in TriFast (Peqlab, Erlangen, Germany) according to the manufacturer's instructions. After DNAse digestion reverse transcription of total RNA was performed using Transcriptor High Fidelity cDNA Synthesis Kit (Roche Diagnostics, Penzberg, Germany). Real-time polymerase chain reaction (RT-PCR) of the respective genes were set up in a total volume of $20 \mu \mathrm{l}$ using $40 \mathrm{ng}$ of cDNA, $500 \mathrm{nM}$ forward and reverse primer and 2x GoTaq ${ }^{\circledR}$ qPCR Master Mix (Promega, Hilden, Germany) according to the manufacturer's protocol. Cycling conditions were as follows: initial denaturation at $95^{\circ} \mathrm{C}$ for $5 \mathrm{~min}$, followed by 40 cycles of $95^{\circ} \mathrm{C}$ for $15 \mathrm{sec}, 58^{\circ} \mathrm{C}$ for $15 \mathrm{sec}$ and $68^{\circ} \mathrm{C}$ for $20 \mathrm{sec}$. For amplification the following primers were used ( $5^{`}->3{ }^{`}$ orientation):

for NCX1: fw: acaagaggtatcgagctggc, rev: atgccatttctcgcctagc;

for NCX2: fw: cgctggtgttcaaaccag, rev: gacgaccacgcaggcat;

for NCX3: fw: gcattgccagggtcattgtct, rev: ccataagggtcaggttggaga;

for NCKX1: fw: tccacgcagaagatggtg, rev: gtgatggaggggatagcg;

for NCKX2: fw: gagacagatacacagagcacagg, rev: gagaatagtacagatcacgccc; 


\section{Cellular Physiology Cell Physiol Biochem 2015;37:1857-1868 \begin{tabular}{l|l|l} 
and BOI: 10.1159/000438547 & $\begin{array}{l}\text { (c) 2015 The Author(s). Published by S. Karger AG, Basel } \\
\text { www.karger.com/cpb }\end{array}$
\end{tabular} \\ Pelzl et al.: $\mathrm{Na}^{+} / \mathrm{Ca}^{2+}$ Exchangers in Therapy Resistant Ovary Carcinoma Cells}

for NCKX3: fw: atgacagcagcaactgcga, rev: tcattgatcaacatgcgactgg;

for NCKX4: fw: tcaaagttcgcaggaggcg, rev: attcactggggccatcaact;

for NCKX5: fw: ctccatcatcggagtttcc, rev: cttcctaccctccctggaa;

for NCKX6: fw: cgtgctggttaccacagtgg, rev: cttccgtggcagggtcag;

for GAPDH: fw: tgagtacgtcgtggagtccac, rev: gtgctaagcagttggtggtg.

Specificity of PCR products was confirmed by analysis of a melting curve. Real-time PCR amplifications were performed on a CFX96 Real-Time System (Bio-Rad) and all experiments were done in duplicate. The house-keeping gene GAPDH (Glycerinaldehyd-3-phosphat-Dehydrogenase) was amplified to standardize the amount of sample RNA. Relative quantification of gene expression was achieved using the $\Delta \mathrm{CT}$ method as described earlier [35, 36].

\section{$\mathrm{Ca}^{2+}$ measurements}

Fura-2 fluorescence was utilized to determine intracellular $\mathrm{Ca}^{2+}$ activity [37]. Cells were loaded with Fura-2/AM ( $2 \mu \mathrm{M}$, Invitrogen, Goettingen, Germany) for $20-60 \mathrm{~min}$ at $37^{\circ} \mathrm{C}$. Cells were excited alternatively at $340 \mathrm{~nm}$ and $380 \mathrm{~nm}$ through an objective (Fluor $40 \times / 1.30$ oil) built in a fluorescence microscope (Axiovert 100, Zeiss, Oberkochen, Germany). Emitted fluorescence intensity was recorded at $505 \mathrm{~nm}$. Data were acquired using specialized computer software (Metafluor, Universal Imaging, Downingtown, USA).

$\mathrm{Na}^{+} / \mathrm{Ca}^{2+}$ exchanger activity was estimated from the changes in cytosolic $\mathrm{Ca}^{2+}$ activity upon replacement of extracellular $\mathrm{Na}^{+}$by $\mathrm{N}$-methyl-d-glucamine (NMDG). The standard $\mathrm{Na}^{+}$containing solution was composed of (in $\mathrm{mM}$ ): $130 \mathrm{NaCl}, 0 \mathrm{KCl}, 2 \mathrm{MgCl}_{2}, 10 \mathrm{HEPES}, 5$ glucose, $\mathrm{pH} 7.4$ and the $\mathrm{Na}^{+}$-free solution of (in mM): 90 NMDG, $0 \mathrm{KCl}, 2 \mathrm{CaCl}_{2}, 2 \mathrm{MgCl}_{2}, 10$ HEPES, 5 glucose, $\mathrm{pH}$ 7.4. For determination of NCKX activity the $\mathrm{Na}^{+}$ containing solution was composed of (in $\mathrm{mM}$ ): $130 \mathrm{NaCl}, 40 \mathrm{KCl}, 20 \mathrm{TAE}^{+}, 2 \mathrm{MgSO}_{4}, 10 \mathrm{HEPES}, 5$ glucose, $\mathrm{pH}$ 7.4 and the $\mathrm{Na}^{+}$-free solution of (in mM): $90 \mathrm{NMDG}, 40 \mathrm{KCl}, 20 \mathrm{TAE}^{+}, 2 \mathrm{CaCl}_{2}, 2 \mathrm{MgCl}_{2}, 10 \mathrm{HEPES}, 5$ glucose, $\mathrm{pH}$ 7.4. For quantification of $\mathrm{Ca}^{2+}$ entry, the slope (delta ratio/s) and peak (delta ratio) were calculated following removal of $\mathrm{Na}^{+}$.

\section{Patch clamp}

Patch clamp experiments were performed at room temperature in voltage-clamp, fast-whole-cell mode according to Hamill et al. [38]. The cells were continuously superfused through a flow system inserted into the dish. Borosilicate glass pipettes (2-5 $\mathrm{M}^{\prime} \Omega$ tip resistance; Harvard Apparatus, Kent, UK) manufactured by a microprocessor-driven DMZ puller (Zeitz, Augsburg, Germany) were used in combination with a MS314 electrical micromanipulator (MW, Märzhäuser, Wetzlar, Germany). The currents were recorded by an EPC-9 amplifier (Heka, Lambrecht, Germany) using Pulse software (Heka) and an ITC-16 Interface (Instrutech, Port Washington, N.Y., USA). The currents were recorded with an acquisition frequency of $10 \mathrm{kHz}$ and 3 $\mathrm{kHz}$ low-pass filtered. The offset potentials between both electrodes were zeroed before sealing. Whole-cell currents elicited by changing the bath solutions were measured during a continuous 40 second square wave voltage pulse to $-80 \mathrm{mV}$. The applied voltages refer to the cytoplasmic face of the membrane with respect to the extracellular space. The outward currents, defined as flow of positive charge from the cytoplasmic to the extracellular membrane face, are positive currents and depicted as outward deflections of the original current traces. To measure $\mathrm{Na}^{+} / \mathrm{Ca}^{2+}$ exchanger-mediated currents, a $\mathrm{Na}^{+}$-based pipette solution was used (in mM): $120 \mathrm{NaCl}, 40 \mathrm{KCl}, 20 \mathrm{TEA}-\mathrm{Cl}, 2 \mathrm{MgCl}_{2}, 2 \mathrm{Mg}$-ATP, $10 \mathrm{HEPES}\left(\mathrm{pH} 7.2 / \mathrm{CsOH}\right.$ ) and $1 \mu \mathrm{M}$ free $\mathrm{Ca}^{2+}$. The external first solution contained (in mM): $130 \mathrm{NaCl}, 20$ TEA-Cl, $2 \mathrm{MgCl}_{2}$, 5 glucose, $10 \mathrm{HEPES}, 0.5 \mathrm{EGTA}$ (pH 7.5/CsOH). $\mathrm{Na}^{+} / \mathrm{Ca}^{2+}$ exchange currents were elicited by switching from the first bath solution to a bath solution that contained (in mM): 130 NMDG-Cl, 20 TEA-Cl, $2 \mathrm{MgCl}_{2}, 2 \mathrm{CaCl}_{2}, 5$ glucose and $10 \mathrm{HEPES}$ (pH 7.5/ $\mathrm{CsOH})$. The $\mathrm{KCl}$ content of the bath solutions was either 0 or $40 \mathrm{mM}$.

\section{Determination of apoptosis}

To determine apoptosis, $10^{5}$ cells $/ 100 \mu \mathrm{l}$ in complete RPMI were centrifuged at $1000 \mathrm{rpm}$ for 5 minutes at $24^{\circ} \mathrm{C}$, added to $200 \mu \mathrm{l}$ of PBS containing $50 \mu \mathrm{g} / \mathrm{ml}$ propidium iodide (Mabtag, Germany) as well as incubated at room temperature in the dark for 10 minutes. The cells were washed once at $1000 \mathrm{rpm}$ for 5 minutes, resuspended in PBS and measured immediately with an excitation wavelength of $488 \mathrm{~nm}$ and an emission wavelength of $585 \mathrm{~nm}$ (FL-2) with flow cytometry [39] utilizing a FACS Calibur (BD, Heidelberg, Germany).

\section{KARGER}




\section{Cellular Physiology Cell Physiol Biochem 2015;37:1857-1868

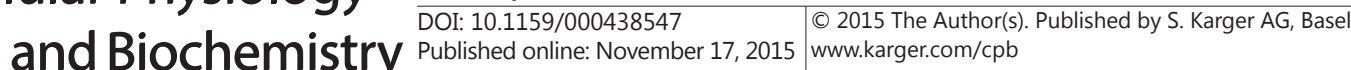 \\ Pelzl et al.: $\mathrm{Na}^{+} / \mathrm{Ca}^{2+}$ Exchangers in Therapy Resistant Ovary Carcinoma Cells}

Statistical ananlysis

Data are provided as means \pm SEM; $n$ represents the number of independent experiments. All data were tested for significance using Student's unpaired two-tailed $t$-test, one sample $t$-test or ANOVA (Dunnett's test) where applicable. Results with $\mathrm{p}<0.05$ were considered statistically significant.

\section{Results}

The present study addressed the putative role of $\mathrm{Na}^{+} / \mathrm{Ca}^{2+}$ exchangers in therapy resistance of ovary carcinoma cells. We first quantified and compared the different transcript levels of the $\mathrm{Na}^{+} / \mathrm{Ca}^{2+}$ exchanger isoforms in therapy sensitive A2780sens and therapy resistant A2780cis ovary carcinoma cells using quantitative real-time-PCR. To this end the respective transcript levels were quantified in therapy sensitive A2780sens and the therapy resistant A2780cis ovary carcinoma cells by using real time-PCR. As illustrated in Fig.1, both cell lines express the NCX isoforms NCX1 and NCX3, but very little NCX2 (Fig.1A). The transcript levels of NCX3, but not those of NCX1 were significantly higher in therapy resistant than in therapy sensitive ovary carcinoma cells (Fig. 1B). As shown in Fig. 2, ovary carcinoma cells further express several NCKX isoforms. The transcript levels of NCKX1 were similar in therapy resistant and in therapy sensitive ovary carcinoma cells. However, the transcript levels of NCKX4, NCKX5, and NCKX6 were significantly higher in therapy resistant as compared to therapy sensitive ovary carcinoma cells (Fig. 2B). NCKX3 transcript levels were not detectable (data not shown).

In the next step, Fura-2 fluorescence was employed to explore whether the differences in NCX and NCKX transcript levels were paralleled by the respective differences in $\mathrm{Na}^{+} / \mathrm{Ca}^{2+}$ exchanger activity. Therefore the $\mathrm{Na}^{+} / \mathrm{Ca}^{2+}$-exchanger activity was estimated from the increase of cytosolic $\mathrm{Ca}^{2+}$ activity $\left(\Delta\left[\mathrm{Ca}^{2+}\right]_{\mathrm{i}}\right)$ after the abrupt replacement of a $\mathrm{Na}^{+}$-based

A a

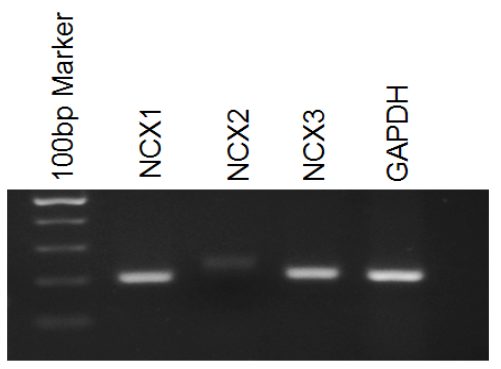

a

B

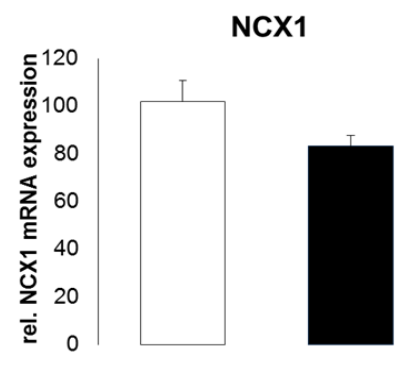

b

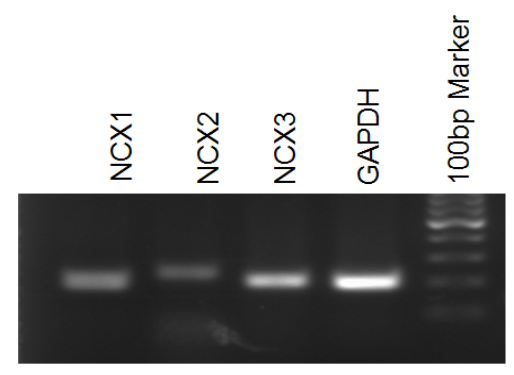

b

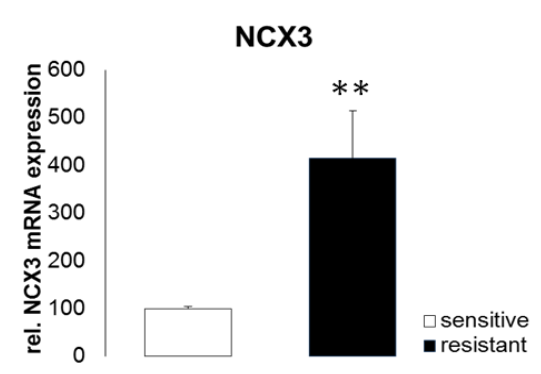

Fig. 1. NCX isoforms expression in therapy sensitive and therapy resistant ovary carcinoma cells. A. Original blots of NCX isoform transcripts in therapy sensitive (a) and therapy resistant (b) ovary carcinoma cells. For comparison, a size marker for NCX1 (195bp), NCX2 (223bp), NCX3 (201bp) and GAPDH (200bp) is shown. B. Arithmetic means ( \pm SEM, $n=7$ preparations) of NCX1 (a) and NCX3 (b) over GAPDH transcript levels in therapy sensitive (white bars) and therapy resistant (black bars) ovary carcinoma cells. ** $(\mathrm{p}<0.01)$ indicates statistically significant difference from therapy sensitive ovary carcinoma cells (student's t-test). 


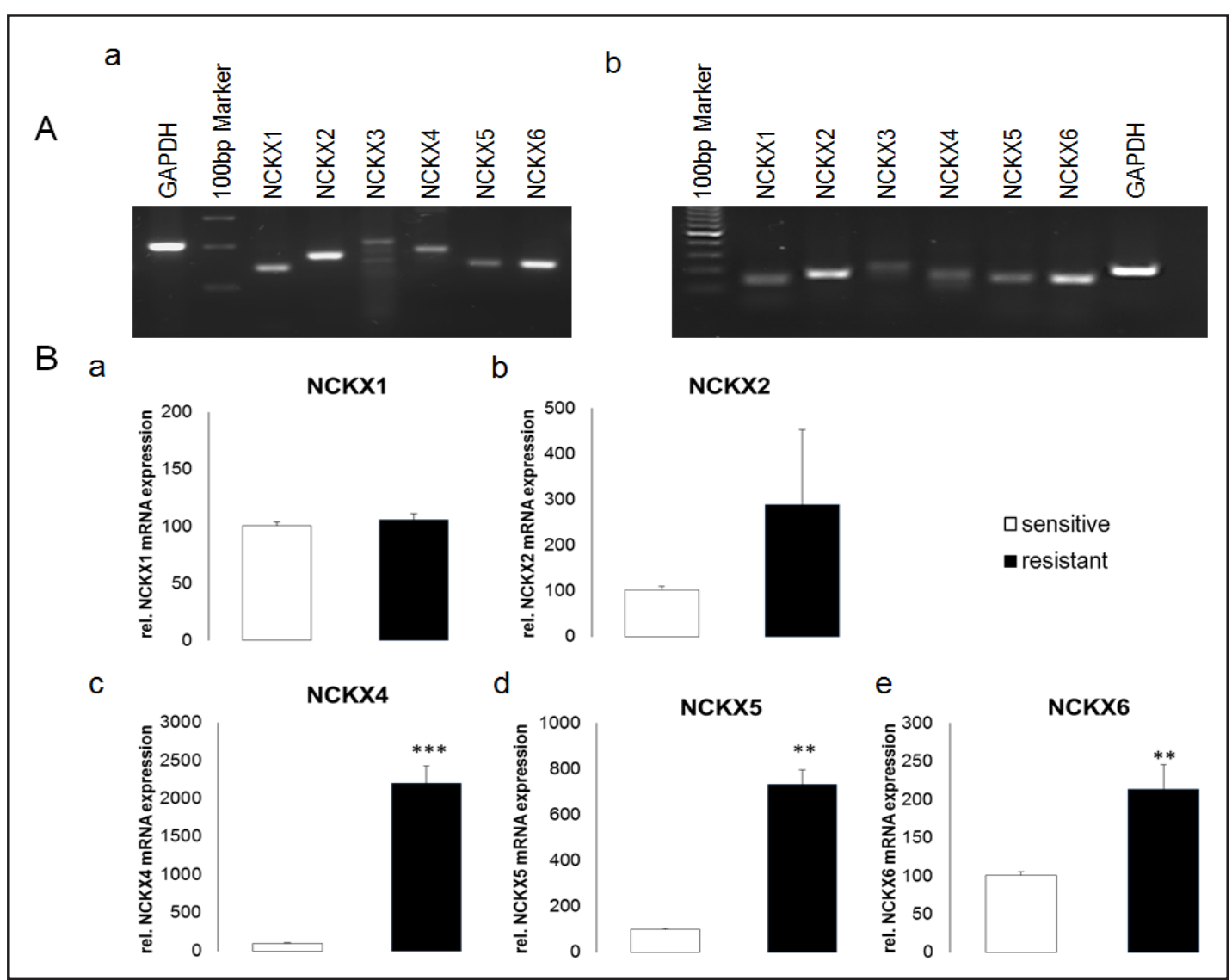

Fig. 2. NCKX isoforms expression in therapy sensitive and therapy resistant ovary carcinoma cells. A. Original blots of NCKX isoform transcripts in therapy sensitive (a) and therapy resistant (b) ovary carcinoma cells. For comparison, a size marker for NCKX1 (138bp), NCKX2 (169bp), NCKX3 (205bp), NCKX4 (179bp), NCKX5 (143bp), NCKX6 (144bp), and GAPDH (200bp) is shown. B. Arithmetic means ( \pm SEM, $n=5$ preparations) of NCKX1(a) and NCKX2 (b), NCKX4 (c), NCKX5 (d), NCKX6 (e) over GAPDH transcript levels in therapy sensitive (white bars) and therapy resistant (black bars) ovary carcinoma cells. ${ }^{* *}(\mathrm{p}<0.01),{ }^{* * *}(\mathrm{p}<0.001)$ indicate statistically significant difference from therapy sensitive ovary carcinoma cells (student's t-test).

$\left(\mathrm{Na}^{+} 130 \mathrm{mM}\right)$ and $\mathrm{Ca}^{2+}$-free extracellular perfusate by a $\mathrm{Na}^{+}$-free and $\mathrm{Ca}^{2+}$-containing $(2$ $\mathrm{mM}$ ) extracellular solution. Prior to $\mathrm{Na}^{+}$removal the Fura2-fluorescence ratio was similar in therapy sensitive $(0.53 \pm 0.01$ a.u., $\mathrm{n}=8)$ and therapy resistant $(0.56 \pm 0.01$ a.u., $\mathrm{n}=10)$ ovary carcinoma cells.

As illustrated in Fig. 3, the removal of external $\mathrm{Na}^{+}$and addition of external $\mathrm{Ca}^{2+}$ was followed by an increase of $\left[\mathrm{Ca}^{2+}\right]_{i}$, which was significantly more pronounced in therapy resistant than in therapy sensitive ovary carcinoma cells. Fig. 3 further illustrates that the increase of cytosolic $\mathrm{Ca}^{2+}$ activity following removal of external $\mathrm{Na}^{+}$and addition of external $\mathrm{Ca}^{2+}$ was virtually abrogated by the $\mathrm{Na}^{+} / \mathrm{Ca}^{2+}$ exchanger inhibitor KB-R7943 $(10 \mu \mathrm{M})$.

Further experiments explored whether $\mathrm{K}^{+}$-dependent $\mathrm{Na}^{+} / \mathrm{Ca}^{2+}$-exchanger activity (NCKX) was different in therapy sensitive and resistant ovary carcinoma cells. To this end, experiments were performed in the presence of high $(40 \mathrm{mM})$ extracellular $\mathrm{K}^{+}$concentration. Again, the increase of cytosolic $\mathrm{Ca}^{2+}$ activity $\left(\Delta\left[\mathrm{Ca}^{2+}\right]_{\mathrm{i}}\right)$ following abrupt replacement of $\mathrm{Na}^{+}$ containing $(130 \mathrm{mM})$ and $\mathrm{Ca}^{2+}$ free extracellular perfusate by $\mathrm{Na}^{+}$free and $\mathrm{Ca}^{2+}$ containing (2 mM) extracellular perfusate was taken as evidence for $\mathrm{Na}^{+} / \mathrm{Ca}^{2+}$-exchanger activity. As illustrated in Fig. 4, in the presence $\mathrm{K}^{+}$, the removal of external $\mathrm{Na}^{+}$and addition of external $\mathrm{Ca}^{2+}$ was followed by an increase of $\left[\mathrm{Ca}^{2+}\right]_{\mathrm{i}^{\prime}}$, which was significantly more pronounced in therapy resistant than in therapy sensitive ovary carcinoma cells. Fig. 4 further illustrates 


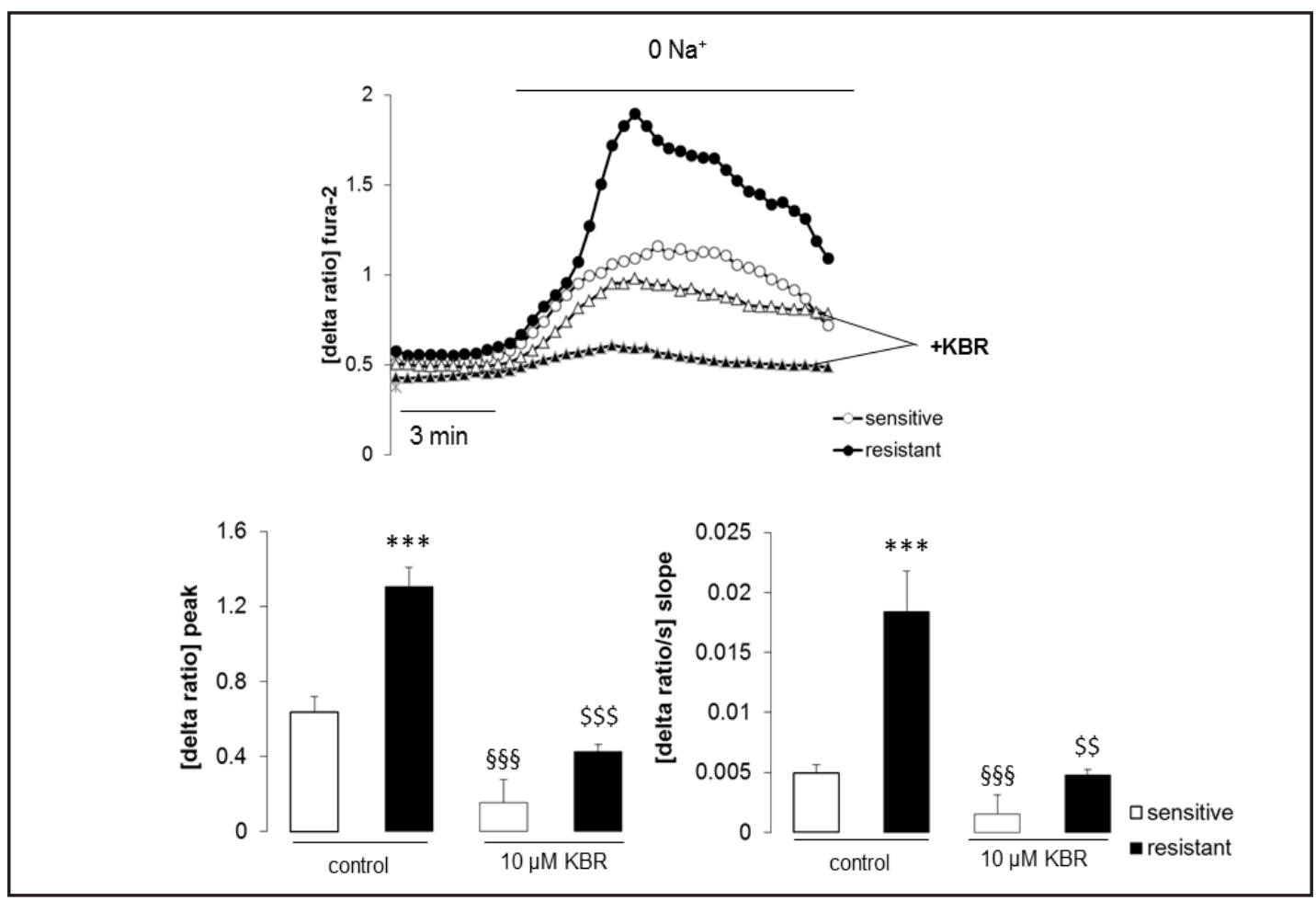

Fig. 3. $\mathrm{NCX}$ mediated $\mathrm{Ca}^{2+}$ entry in therapy sensitive and therapy resistant ovary carcinoma cells. A. Representative original tracings showing intracellular $\mathrm{Ca}^{2+}$ concentrations in Fura-2/AM loaded therapy sensitive (open symbols) and therapy resistant (closed symbols) ovary carcinoma cells in absence (circles) or presence (triangles) of the NCX inhibitor KB-R7943 $(10 \mu \mathrm{M})$ prior to and following removal of external $\mathrm{Na}^{+}(0$ $\mathrm{Na}^{+}$) and adding $5 \mathrm{mM} \mathrm{K}^{+}$. B,C. Arithmetic means ( \pm SEM, $\mathrm{n}=109$ - 156- cells from 4- 6 group) of the peak (B) and slope $(\mathrm{C})$ of the change in intracellular $\mathrm{Ca}^{2+}$ concentrations in therapy sensitive (white bars) and therapy resistant (black bars) ovary carcinoma cells prior to and following removal of external $\mathrm{Na}^{+}\left(0 \mathrm{Na}^{+}\right)$and adding $5 \mathrm{mM} \mathrm{K}^{+}$in the absence (left bars, -KBR) and presence (right bars, + KBR) of the NCX inhibitor KB-R7943 $(10 \mu \mathrm{M}){ }^{* *}(\mathrm{p}<0.01),{ }^{* * *}(\mathrm{p}<0.001)$ indicate statistically significant difference from therapy sensitive ovary carcinoma cells; $\$(p<0.01), \$ \$(p<0.001)$ indicates statistical significant difference from absence of KBR7943 in the therapy resistant ovary carcinoma cells; $\S \S \S(\mathrm{p}<0.001)$ indicates statistical significant difference from the absence of KB-R7943 in the sensitive ovary carcinoma cells (ANOVA).

that the increase of cytosolic $\mathrm{Ca}^{2+}$ activity following removal of external $\mathrm{Na}^{+}$and addition of external $\mathrm{Ca}^{2+}$ was virtually abrogated by NCX inhibitor KB-R7943 $(10 \mu \mathrm{M})$.

In order to further examine the functionality and membrane insertion of the $\mathrm{Na}^{+} /$ $\mathrm{Ca}^{2+}$ ex-changers, whole cell currents were measured utilizing the patch clamp technique. Again, the current was recorded following abrupt replacement of $\mathrm{Na}^{+}$-containing $/ \mathrm{Ca}^{2+}$-free extracellular perfusate by $\mathrm{Na}^{+}$-free $/ \mathrm{Ca}^{2+}$-containing $(2 \mathrm{mM})$ solution. The removal of external $\mathrm{Na}^{+}$and addition of $\mathrm{Ca}^{2+}$ was followed by an outward current, which was significantly larger in therapy resistant than in therapy sensitive ovary carcinoma cells (Fig. 5).

A further series of experiments addressed the impact of the $\mathrm{Na}^{+} / \mathrm{Ca}^{2+}$ exchangers on the therapy resistance of ovary carcinoma cells. To this end, therapy resistant and therapy sensitive ovary carcinoma cells were treated with cisplatin $(100 \mu \mathrm{M}, 24 \mathrm{~h})$ in the absence or presence of the $\mathrm{Na}^{+} / \mathrm{Ca}^{2+}$ exchanger inhibitor KB-R7943 $(10 \mu \mathrm{M})$. Cisplatin treatment significantly increased the percentage of propodium iodide containing ovary carcinoma cells, an effect significantly more pronounced in therapy sensitive than in therapy resistant ovary carcinoma cells (Fig. 6). The additional treatment with KB-R7943 did not significantly affect cell death of therapy sensitive ovary carcinoma cells; but significantly increased the percentage of apoptotic therapy resistant ovary carcinoma cells (Fig. 6C). 


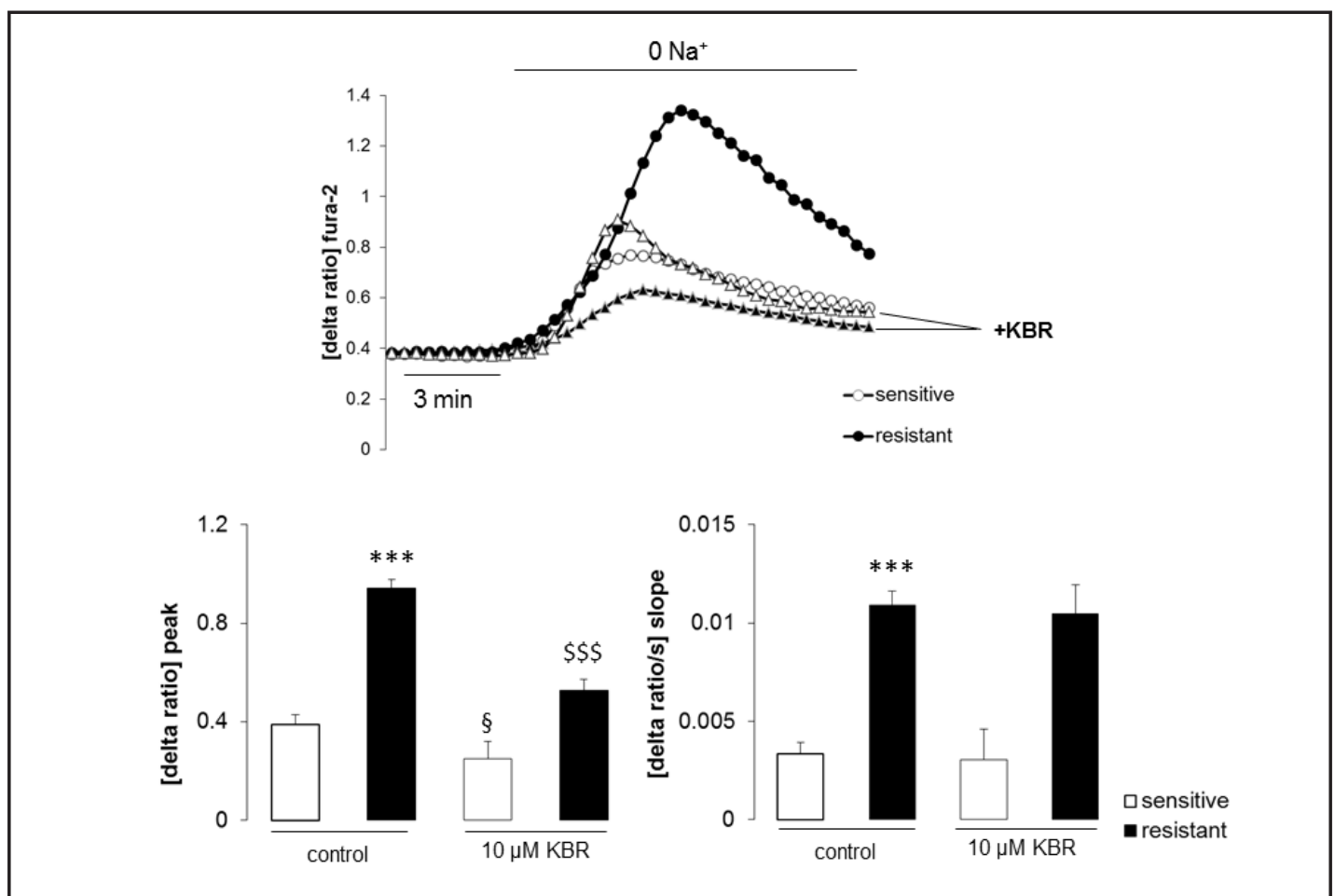

Fig. 4. NCKX mediated $\mathrm{Ca}^{2+}$ entry in therapy sensitive and therapy resistant ovary carcinoma cells. A. Representative original tracings showing intracellular $\mathrm{Ca}^{2+}$ concentrations in Fura-2/AM loaded therapy sensitive (open symbols) and therapy resistant (closed symbols) ovary carcinoma cells in absence (circles) or presence (triangles) of the NCX inhibitor KB-R7943 $(10 \mu \mathrm{M})$ before and following removal of external $\mathrm{Na}^{+}$ $\left(0 \mathrm{Na}^{+}\right)$, addition of $40 \mathrm{mM} \mathrm{K}^{+}$and application of $\mathrm{K}^{+}$channel blocker TEA ${ }^{+}$. B,C. Arithmetic means $( \pm$SEM, $\mathrm{n}$ = 133-179- cells from 4-5 group) of the peak (B) and slope (C) of the change in intracellular $\mathrm{Ca}^{2+}$ concentrations in therapy sensitive (white bars) and therapy resistant (black bars) ovary carcinoma cells prior to and following removal of external $\mathrm{Na}^{+}\left(0 \mathrm{Na}^{+}\right)$in the presence of $40 \mathrm{mM} \mathrm{K}^{+}$in the absence (left bars, -KBR) and presence (right bars, + KBR) of the NCX inhibitor KB-R7943 $(10 \mu \mathrm{M})$. *** $(\mathrm{p}<0.001)$ indicate statistically significant difference from therapy sensitive ovary carcinoma cells; $\$ \$ \$(p<0.001)$ indicates statistical significant difference from the absence of KB-R7943 in the therapy resistant ovary carcinoma cells; $\S(\mathrm{p}<0.05)$ indicates statistical significant difference from the absence of KB-R7943 in the sensitive ovary carcinoma cells (ANOVA).

\section{Discussion}

The present study revealed the expression of several $\mathrm{Na}^{+} / \mathrm{Ca}^{2+}$ exchanger isoforms in ovary carcinoma cells. In both, therapy resistant and therapy sensitive ovary carcinoma cells, transcript levels were detected encoding the $\mathrm{Na}^{+} / \mathrm{Ca}^{2+}$ exchangers NCX1, NCX3, NCKX1, NCKX2, NCKX4, NCKX5, and NCKX6. More importantly, the transcript levels of NCX3 and of NCKX4, NCKX5 and NCKX6 were more abundant in therapy resistant than in therapy sensitive ovary carcinoma cells. The increased abundance of mRNA encoding the respective $\mathrm{Na}^{+} / \mathrm{Ca}^{2+}$ exchanger isoforms was paralleled by similar increases of $\mathrm{Na}^{+} / \mathrm{Ca}^{2+}$ exchanger activities.

Previous observations disclosed increased expression of both, Orai1 and STIM1 in therapy resistant as compared to therapy sensitive ovary carcinoma cells [21]. The increased expression of Orai1 and STIM1 was paralleled by increased store operated $\mathrm{Ca}^{2+}$ entry (SOCE) in therapy resistant ovary carcinoma cells. Pharmacological inhibition of Orai1 augmented cisplatin induced apoptosis of therapy resistant ovary carcinoma cells and virtually abrogated the differences in cisplatin sensitivity between therapy sensitive and therapy resistant ovary carcinoma cells [21]. The Orai isoforms Orai1, 2, or 3 [6-9] and their regulators STIM 1 or 2 


\section{Cellular Physiology Cell Physiol Biochem 2015;37:1857-1868

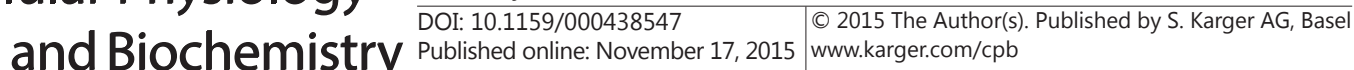

Fig. 5. $\mathrm{Na}^{+} / \mathrm{Ca}^{2+}$ exchanger currents in therapy sensitive and therapy resistant ovary carcinoma cells. A,B. Original tracings of whole cell currents in therapy sensitive (A) and therapy resistant (B) ovary carcinoma cells recorded at $-80 \mathrm{mV}$ during the switch between external solutions that contained $40 \mathrm{mM} \mathrm{K}^{+}$and either $130 \mathrm{mM} \mathrm{Na}^{+}$ and no $\mathrm{Ca}^{2+}$ or $2 \mathrm{mM} \mathrm{Ca}^{2+}$ and no $\mathrm{Na}^{+}$. The internal solution stimulated $\mathrm{Na}^{+}-$and $\mathrm{Ca}^{2+}$ overload ( $1 \mu \mathrm{M}$ free $\mathrm{Ca}^{2+}, 120 \mathrm{mM} \mathrm{Na}^{+}, 40 \mathrm{mM} \mathrm{K}{ }^{+}$). Cesium and $\mathrm{TEA}^{+}$were present in the solutions to block $\mathrm{K}^{+}$channel currents. $\mathrm{C}$. Arithmetic means $( \pm \mathrm{SEM}$, $\mathrm{n}=5-9$ cells) current density changes $(\Delta \mathrm{I}, \mathrm{pA} / \mathrm{pF})$ at $-80 \mathrm{mV}$ in therapy sensitive (white bars) and therapy resistant (black bars) ovary carcinoma cells induced by the switch between external solutions containing (in mM) $40 \mathrm{~K}^{+}$and $130 \mathrm{Na}^{+}, 0 \mathrm{Ca}^{2+}$ or $0 \mathrm{Na}^{+}, 2 \mathrm{Ca}^{2+}$. ${ }^{* *}(\mathrm{p}<0.01)$ indicates statistically significant difference from therapy sensitive ovary carcinoma cells (student's t-test).

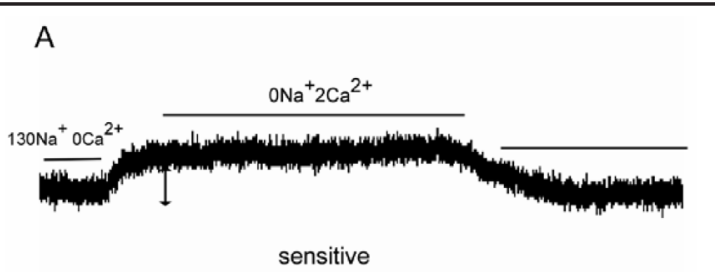

B

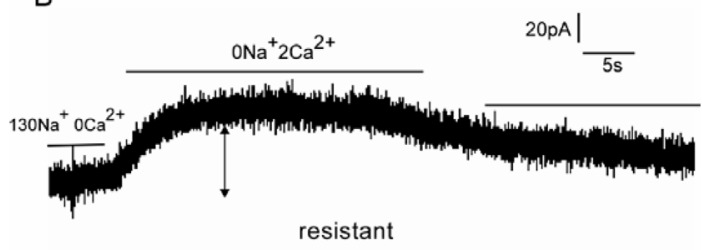

C

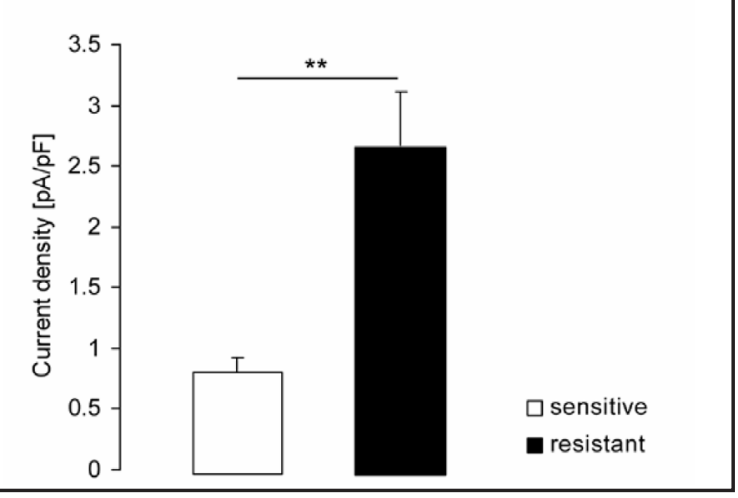

$[12,13,15]$ have been implicated in survival, proliferation, and migration of tumor cells [16-20, 40-48].

At first glance, it appears counterintuitive that both enhanced $\mathrm{Ca}^{2+}$ entry and accelerated $\mathrm{Ca}^{2+}$ extrusion confer resistance to apoptosis. However, the concerted action of SOCE and $\mathrm{Ca}^{2+}$ extrusion mechanisms such as $\mathrm{Na}^{+} / \mathrm{Ca}^{2+}$ exchangers lead to the apperance of $\mathrm{Ca}^{2+}$ oscillations [49] which are decisive in the regulation of diverse cellular functions [23, 50-53], such as entrance into the $S$ and the $M$ phase of the cell cycle $[54,55]$ and support of tumor cell survival $[56,57]$. Those $\mathrm{Ca}^{2+}$ oscillations are equally dependent on timely entry and timely extrusion of $\mathrm{Ca}^{2+}$. Failure to extrude $\mathrm{Ca}^{2+}$ leads to sustained increase of cytosolic $\mathrm{Ca}^{2+}$ activity, which is a well-known trigger of apoptosis [51, 53, 58-66]. Accordingly, fine tuning of both, $\mathrm{Ca}^{2+}$ entry and $\mathrm{Ca}^{2+}$ extrusion is required in order to establish the adequate $\mathrm{Ca}^{2+}$ oscillations.

In theory, other NCX or NCKX isoforms may be relevant for survival and therapy resistance of other tumor cells. Similarly, other Orai/STIM isoforms [67-69] or other $\mathrm{Ca}^{2+}$ channels [70-75] may confer survival and thus establish therapy resistance of other tumor cell types. Disruption of $\mathrm{Ca}^{2+}$ oscillations by pharmacological inhibition of the respective channels, of the respective $\mathrm{Na}^{+} / \mathrm{Ca}^{2+}$ exchanger isoforms and/or the respective regulating kinases may enhance sensitivity to cytostatic therapy or radiation.

In conclusion, ovary carcinoma cells express several $\mathrm{Na}^{+} / \mathrm{Ca}^{2+}$ exchanger isoforms. The expression of several of those isoforms and thus $\mathrm{Na}^{+} / \mathrm{Ca}^{2+}$ exchanger activity is higher in therapy resistant than in therapy sensitive ovary carcinoma cells and pharmacological inhibition of $\mathrm{Na}^{+} / \mathrm{Ca}^{2+}$ exchange sensitises the therapy resistant ovary carcinoma cells to cisplatin. Accordingly, $\mathrm{Na}^{+} / \mathrm{Ca}^{2+}$ exchangers may be novel targets in the attempt to overcome therapy resistance of tumor cells. 
A

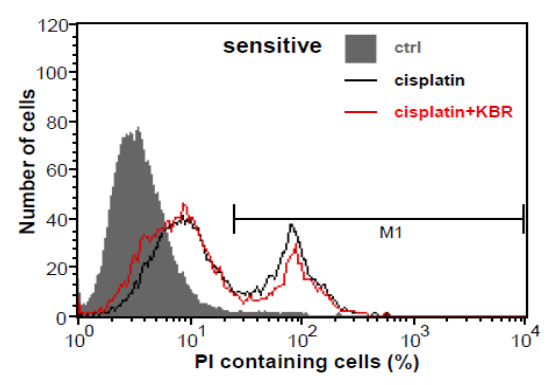

B

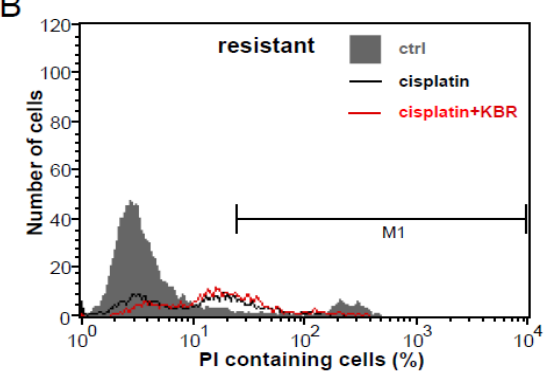

C

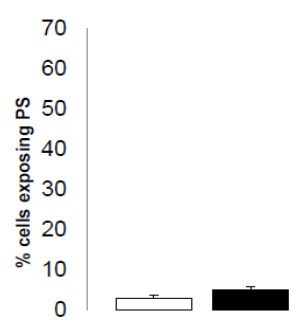

Pi FACS



Fig. 6. Effect of NCX inhibitor KB-R7943 on cisplatin induced cell death of therapy sensitive and therapy resistant ovary carcinoma cells. A,B. Original histograms of propodium iodide abundance in therapy sensitive (A) and therapy resistant (B) ovary carcinoma cells prior to (grey areas) and following cisplatin treatment in the absence (black line) and presence (red line) of NCX inhibitor KB-R7943 $(10 \mu \mathrm{M})$. C. Arithmetic means ( \pm SEM, $n=6-8$ ) of the percentage of therapy sensitive (white bars) and therapy resistant (black bars) ovary carcinoma cells containing propodium iodide prior to (control, left bars) and following (cisplatin, middle and right bars) treatment with cisplatin $(100 \mu \mathrm{M}, 24 \mathrm{~h})$ in the absence (middle bars, - KBR) or presence (right bars, + KBR) of NCX inhibitor KB-R7943 $(10 \mu \mathrm{M}) .{ }^{* *}(\mathrm{p}<0.01)$, indicate statistically significant difference from the absence of KB-R7943 $(10 \mu \mathrm{M})$ in cisplatin treated resistant ovary carcinoma cells (student's t-test).

\section{Acknowledgements}

This study was supported by the Brigitte-Schlieben-Lange-Programm and the Open Access Publishing Fund of Tuebingen University.

\section{Disclosure Statement}

The authors of this manuscript state that they have no conflicts of interest to declare.

\section{References}

1 Becchetti A, Arcangeli A: Integrins and ion channels in cell migration: implications for neuronal development, wound healing and metastatic spread. Adv Exp Med Biol 2010;674:107-123.

2 Burgoyne RD: Neuronal calcium sensor proteins: generating diversity in neuronal Ca2+ signalling. Nat Rev Neurosci 2007;8:182-193.

3 Orrenius S, Zhivotovsky B, Nicotera P: Regulation of cell death: the calcium-apoptosis link. Nat Rev Mol Cell Biol 2003;4:552-565.

4 Roderick HL, Cook SJ: Ca2 + signalling checkpoints in cancer: remodelling Ca2+ for cancer cell proliferation and survival. Nat Rev Cancer 2008;8:361-375. 


\section{Cellular Physiology Cell Physiol Biochem 2015;37:1857-1868 \begin{tabular}{l|l|l}
\hline DOI: 10.1159/000438547 & $\begin{array}{l}\text { C } 2015 \text { The Author(s). Published by S. Karger AG, Basel } \\
\text { www.karger.com/cpb }\end{array}$ \\
\hline
\end{tabular}}

Pelzl et al.: $\mathrm{Na}^{+} / \mathrm{Ca}^{2+}$ Exchangers in Therapy Resistant Ovary Carcinoma Cells

$5 \quad$ Salter RD, Watkins SC: Dendritic cell altered states: what role for calcium? Immunol Rev 2009;231:278288.

6 Prakriya M, Feske S, Gwack Y, Srikanth S, Rao A, Hogan PG: Orai1 is an essential pore subunit of the CRAC channel. Nature 2006;443:230-233.

7 Putney JW Jr: New molecular players in capacitative Ca2+ entry. J Cell Sci 2007;120:1959-1965.

8 Vig M, Peinelt C, Beck A, Koomoa DL, Rabah D, Koblan-Huberson M, Kraft S, Turner H, Fleig A, Penner R, Kinet JP: CRACM1 is a plasma membrane protein essential for store-operated Ca2+ entry. Science 2006;312:1220-1223.

9 Yeromin AV, Zhang SL, Jiang W, Yu Y, Safrina O, Cahalan MD: Molecular identification of the CRAC channel by altered ion selectivity in a mutant of Orai. Nature 2006;443:226-229.

10 Zhang SL, Kozak JA, Jiang W, Yeromin AV, Chen J, Yu Y, Penna A, Shen W, Chi V, Cahalan MD: Store-dependent and -independent modes regulating $\mathrm{Ca} 2+$ release-activated $\mathrm{Ca} 2+$ channel activity of human Orai1 and Orai3. J Biol Chem 2008;283:17662-17671.

11 Fahrner M, Muik M, Derler I, Schindl R, Fritsch R, Frischauf I, Romanin C: Mechanistic view on domains mediating STIM1-Orai coupling. Immunol Rev 2009;231:99-112.

12 Peinelt C, Vig M, Koomoa DL, Beck A, Nadler MJ, Koblan-Huberson M, Lis A, Fleig A, Penner R, Kinet JP: Amplification of CRAC current by STIM1 and CRACM1 (Orai1). Nat Cell Biol 2006;8:771-773.

13 Penna A, Demuro A, Yeromin AV, Zhang SL, Safrina O, Parker I, Cahalan MD: The CRAC channel consists of a tetramer formed by Stim-induced dimerization of Orai dimers. Nature 2008;456:116-120.

14 Smyth JT, Hwang SY, Tomita T, DeHaven WI, Mercer JC, Putney JW: Activation and regulation of storeoperated calcium entry. J Cell Mol Med 2010;14:2337-2349.

15 Zhang SL, Yu Y, Roos J, Kozak JA, Deerinck TJ, Ellisman MH, Stauderman KA, Cahalan MD: STIM1 is a Ca2+ sensor that activates CRAC channels and migrates from the Ca2+ store to the plasma membrane. Nature 2005;437:902-905.

16 Bergmeier W, Weidinger C, Zee I, Feske S: Emerging roles of store-operated Ca ( $2+$ ) entry through STIM and ORAI proteins in immunity, hemostasis and cancer. Channels (Austin) 2013;7:379-391.

17 Capiod T: The need for calcium channels in cell proliferation. Recent Pat Anticancer Drug Discov 2013;8:417.

18 Courjaret R, Machaca K: STIM and Orai in cellular proliferation and division. Front Biosci (Elite Ed) 2012;4:331-341.

19 Moccia F, Dragoni S, Lodola F, Bonetti E, Bottino C, Guerra G, Laforenza U, Rosti V, Tanzi F: Store-dependent $\mathrm{Ca}(2+)$ entry in endothelial progenitor cells as a perspective tool to enhance cell-based therapy and adverse tumour vascularization. Curr Med Chem 2012;19:5802-5818.

20 Prevarskaya N, Skryma R, Shuba Y: Calcium in tumour metastasis: new roles for known actors. Nat Rev Cancer 2011;11:609-618.

21 Schmidt S, Liu G, Liu G, Yang W, Honisch S, Pantelakos S, Stournaras C, Honig A, Lang F: Enhanced Orai1 and STIM1 expression as well as store operated Ca2+ entry in therapy resistant ovary carcinoma cells. Oncotarget 2014;5:4799-4810.

22 Berridge MJ: Calcium microdomains: organization and function. Cell Calcium 2006;40:405-412.

23 Berridge MJ, Bootman MD, Roderick HL: Calcium signalling: dynamics, homeostasis and remodelling. Nat Rev Mol Cell Biol 2003;4:517-529.

24 Clapham DE: Calcium signaling. Cell 2007;131:1047-1058.

25 Herchuelz A, Kamagate A, Ximenes H, Van Eylen F: Role of Na/Ca exchange and the plasma membrane Ca2+-ATPase in beta cell function and death. Ann N Y Acad Sci 2007;1099:456-467.

26 Khananshvili D: Sodium-calcium exchangers (NCX): molecular hallmarks underlying the tissue-specific and systemic functions. Pflugers Arch 2014;466:43-60.

27 Visser F, Lytton J: K+ -dependent $\mathrm{Na}+/ \mathrm{Ca} 2+$ exchangers: key contributors to Ca2+ signaling. Physiology (Bethesda) 2007;22:185-192.

28 Visser F, Valsecchi V, Annunziato L, Lytton J: Exchangers NCKX2, NCKX3, and NCKX4: identification of Thr551 as a key residue in defining the apparent K(+) affinity of NCKX2. J Biol Chem 2007;282:4453-4462.

29 Lytton J: $\mathrm{Na}+/ \mathrm{Ca} 2+$ exchangers: three mammalian gene families control Ca2+ transport. Biochem J 2007;406:365-382.

30 Blaustein MP, Lederer WJ: Sodium/calcium exchange: its physiological implications. Physiol Rev 1999;79:763-854. 


\section{Cellular Physiology Cell Physiol Biochem 2015;37:1857-1868 \begin{tabular}{l|l|l} 
DOI: 10.1159/000438547 & $\begin{array}{l}\text { (c) 2015 The Author(s). Published by S. Karger AG, Basel } \\
\text { www.karger.com/cpb }\end{array}$
\end{tabular} \\ Pelzl et al.: $\mathrm{Na}^{+} / \mathrm{Ca}^{2+}$ Exchangers in Therapy Resistant Ovary Carcinoma Cells}

31 Behrens BC, Hamilton TC, Masuda H, Grotzinger KR, Whang-Peng J, Louie KG, Knutsen T, McKoy WM, Young RC, Ozols RF: Characterization of a cis-diamminedichloroplatinum(II)-resistant human ovarian cancer cell line and its use in evaluation of platinum analogues. Cancer Res 1987;47:414-418.

32 Louie KG, Behrens BC, Kinsella TJ, Hamilton TC, Grotzinger KR, McKoy WM, Winker MA, Ozols RF: Radiation survival parameters of antineoplastic drug-sensitive and -resistant human ovarian cancer cell lines and their modification by buthionine sulfoximine. Cancer Res 1985;45:2110-2115.

33 Strese S, Fryknas M, Larsson R, Gullbo J: Effects of hypoxia on human cancer cell line chemosensitivity. BMC Cancer 2013;13:331.

34 Kiedrowski L, Czyz A, Baranauskas G, Li XF, Lytton J: Differential contribution of plasmalemmal Na/Ca exchange isoforms to sodium-dependent calcium influx and NMDA excitotoxicity in depolarized neurons. J Neurochem 2004;90:117-128.

35 Borst O, Munzer P, Gatidis S, Schmidt EM, Schonberger T, Schmid E, Towhid ST, Stellos K, Seizer P, May AE, Lang F, Gawaz M: The inflammatory chemokine CXC motif ligand 16 triggers platelet activation and adhesion via CXC motif receptor 6-dependent phosphatidylinositide 3-kinase/Akt signaling. Circ Res 2012;111:1297-1307.

36 Feger M, Fajol A, Lebedeva A, Meissner A, Michael D, Voelkl J, Alesutan I, Schleicher E, Reichetzeder C, Hocher B, Qadri SM, Lang F: Effect of carbon monoxide donor CORM-2 on vitamin D3 metabolism. Kidney Blood Press Res 2013;37:496-505.

37 Bhavsar SK, Schmidt S, Bobbala D, Nurbaeva MK, Hosseinzadeh Z, Merches K, Fajol A, Wilmes J, Lang F: AMPKalpha1-Sensitivity of Orai1 and Ca Entry in T - Lymphocytes. Cell Physiol Biochem 2013;32:687-698.

38 Hamill OP, Marty A, Neher E, Sakmann B, Sigworth FJ: Improved patch-clamp techniques for highresolution current recording from cells and cell-free membrane patches. Pflugers Arch 1981;391:85-100.

39 Rotte A, Pasham V, Bhandaru M, Bobbala D, Zelenak C, Lang F: Rapamycin sensitive ROS formation and $\mathrm{Na}(+) / \mathrm{H}(+)$ exchanger activity in dendritic cells. Cell Physiol Biochem 2012;29:543-550.

40 Baryshnikov SG, Pulina MV, Zulian A, Linde CI, Golovina VA: Orai1, a critical component of store-operated $\mathrm{Ca} 2+$ entry, is functionally associated with $\mathrm{Na}+\mathrm{Ca} 2+$ exchanger and plasma membrane $\mathrm{Ca} 2+$ pump in proliferating human arterial myocytes. Am J Physiol Cell Physiol 2009;297:C1103-C1112.

41 Berra-Romani R, Mazzocco-Spezzia A, Pulina MV, Golovina VA: Ca2+ handling is altered when arterial myocytes progress from a contractile to a proliferative phenotype in culture. Am J Physiol Cell Physiol 2008;295:C779-C790.

42 Faouzi M, Hague F, Potier M, Ahidouch A, Sevestre H, Ouadid-Ahidouch H: Down-regulation of Orai3 arrests cell-cycle progression and induces apoptosis in breast cancer cells but not in normal breast epithelial cells. J Cell Physiol 2011;226:542-551.

43 Motiani RK, Abdullaev IF, Trebak M: A novel native store-operated calcium channel encoded by Orai3: selective requirement of Orai3 versus Orai1 in estrogen receptor-positive versus estrogen receptornegative breast cancer cells. J Biol Chem 2010;285:19173-19183.

44 Qu B, Al-Ansary D, Kummerow C, Hoth M, Schwarz EC: ORAI-mediated calcium influx in T cell proliferation, apoptosis and tolerance. Cell Calcium 2011;50:261-269.

45 Schmid E, Bhandaru M, Nurbaeva MK, Yang W, Szteyn K, Russo A, Leibrock C, Tyan L, Pearce D, Shumilina E, Lang F: SGK3 regulates $\mathrm{Ca}(2+)$ entry and migration of dendritic cells. Cell Physiol Biochem 2012;30:14231435.

46 Chen YF, Chiu WT, Chen YT, Lin PY, Huang HJ, Chou CY, Chang HC, Tang MJ, Shen MR: Calcium store sensor stromal-interaction molecule 1-dependent signaling plays an important role in cervical cancer growth, migration, and angiogenesis. Proc Natl Acad Sci U S A 2011;108:15225-15230.

47 Flourakis M, Lehen'kyi V, Beck B, Raphael M, Vandenberghe M, Abeele FV, Roudbaraki M, Lepage G, Mauroy B, Romanin C, Shuba Y, Skryma R, Prevarskaya N: Orai1 contributes to the establishment of an apoptosisresistant phenotype in prostate cancer cells. Cell Death Dis 2010;1:e75.

48 Prevarskaya N, Ouadid-Ahidouch H, Skryma R, Shuba Y: Remodelling of Ca2+ transport in cancer: how it contributes to cancer hallmarks? Philos Trans R Soc Lond B Biol Sci 2014;369:20130097.

49 Lang F, Friedrich F, Kahn E, Woll E, Hammerer M, Waldegger S, Maly K, Grunicke H: Bradykinininduced oscillations of cell membrane potential in cells expressing the Ha-ras oncogene. J Biol Chem 1991;266:4938-4942.

50 Berridge MJ, Bootman MD, Lipp P: Calcium--a life and death signal. Nature 1998;395:645-648. 


\section{Cellular Physiology Cell Physiol Biochem 2015;37:1857-1868 \begin{tabular}{l|l|l} 
DOI: 10.1159/000438547 & $\begin{array}{l}\text { C } 2015 \text { The Author(s). Published by S. Karger AG, Basel } \\
\text { wwwwkarger.com/cpb }\end{array}$
\end{tabular} \\ Pelzl et al.: $\mathrm{Na}^{+} / \mathrm{Ca}^{2+}$ Exchangers in Therapy Resistant Ovary Carcinoma Cells}

51 Berridge MJ, Lipp P, Bootman MD: The versatility and universality of calcium signalling. Nat Rev Mol Cell Biol 2000;1:11-21.

52 Lang F, Busch GL, Ritter M, Volkl H, Waldegger S, Gulbins E, Haussinger D: Functional significance of cell volume regulatory mechanisms. Physiol Rev 1998;78:247-306.

53 Parekh AB, Penner R: Store depletion and calcium influx. Physiol Rev 1997;77:901-930.

54 Steinhardt RA, Alderton J: Intracellular free calcium rise triggers nuclear envelope breakdown in the sea urchin embryo. Nature 1988;332:364-366.

55 Taylor JT, Zeng XB, Pottle JE, Lee K, Wang AR, Yi SG, Scruggs JA, Sikka SS, Li M: Calcium signaling and T-type calcium channels in cancer cell cycling. World J Gastroenterol 2008;14:4984-4991.

56 Heise N, Palme D, Misovic M, Koka S, Rudner J, Lang F, Salih HR, Huber SM, Henke G: Non-selective cation channel-mediated Ca2+-entry and activation of Ca2+/calmodulin-dependent kinase II contribute to G2/M cell cycle arrest and survival of irradiated leukemia cells. Cell Physiol Biochem 2010;26:597-608.

57 Parkash J, Asotra K: Calcium wave signaling in cancer cells. Life Sci 2010;87:587-595.

58 Damm TB, Egli M: Calcium's role in mechanotransduction during muscle development. Cell Physiol Biochem 2014;33:249-272.

59 Fang KM, Chang WL, Wang SM, Su MJ, Wu ML: Arachidonic acid induces both Na+ and Ca2+ entry resulting in apoptosis. J Neurochem 2008;104:1177-1189.

60 Green DR, Reed JC: Mitochondria and apoptosis. Science 1998;281:1309-1312.

61 Lang F, Hoffmann EK: Role of ion transport in control of apoptotic cell death. Compr Physiol 2012;2:20372061.

62 Liu XH, Kirschenbaum A, Yu K, Yao S, Levine AC: Cyclooxygenase-2 suppresses hypoxia-induced apoptosis via a combination of direct and indirect inhibition of p53 activity in a human prostate cancer cell line. J Biol Chem 2005;280:3817-3823.

63 Shaik N, Zbidah M, Lang F: Inhibition of $\mathrm{Ca}(2+)$ entry and suicidal erythrocyte death by naringin. Cell Physiol Biochem 2012;30:678-686.

64 Spassova MA, Soboloff J, He LP, Hewavitharana T, Xu W, Venkatachalam K, van Rossum DB, Patterson RL, Gill DL: Calcium entry mediated by SOCs and TRP channels: variations and enigma. Biochim Biophys Acta 2004;1742:9-20.

65 Svoboda N, Pruetting S, Grissmer S, Kerschbaum HH: cAMP-dependent chloride conductance evokes ammonia-induced blebbing in the microglial cell line, BV-2. Cell Physiol Biochem 2009;24:53-64.

66 Towhid ST, Schmidt EM, Tolios A, Munzer P, Schmid E, Borst O, Gawaz M, Stegmann E, Lang F: Stimulation of platelet death by vancomycin. Cell Physiol Biochem 2013;31:102-112.

67 Faouzi M, Kischel P, Hague F, Ahidouch A, Benzerdjeb N, Sevestre H, Penner R, Ouadid-Ahidouch H: ORAI3 silencing alters cell proliferation and cell cycle progression via c-myc pathway in breast cancer cells. Biochim Biophys Acta 2013;1833:752-760.

68 Hoth M, Niemeyer BA: The neglected CRAC proteins: Orai2, Orai3, and STIM2. Curr Top Membr 2013;71:237-271.

69 Motiani RK, Hyzinski-Garcia MC, Zhang X, Henkel MM, Abdullaev IF, Kuo YH, Matrougui K, Mongin AA, Trebak M: STIM1 and Orai1 mediate CRAC channel activity and are essential for human glioblastoma invasion. Pflugers Arch 2013;465:1249-1260.

70 Chen J, Luan Y, Yu R, Zhang Z, Zhang J, Wang W: Transient receptor potential (TRP) channels, promising potential diagnostic and therapeutic tools for cancer. Biosci Trends 2014;8:1-10.

71 Kondratskyi A, Yassine M, Kondratska K, Skryma R, Slomianny C, Prevarskaya N: Calcium-permeable ion channels in control of autophagy and cancer. Front Physiol 2013;4:272.

72 Lang F, Stournaras C: Ion channels in cancer: future perspectives and clinical potential. Philos Trans R Soc Lond B Biol Sci 2014;369:20130108.

73 Loughlin KR: Calcium channel blockers and prostate cancer. Urol Oncol 2014;10.1016/j. urolonc.2013.08.001

74 Nielsen N, Lindemann O, Schwab A: TRP channels and STIM/ORAI proteins: Sensors and effectors of cancer and stroma cell migration. Br J Pharmacol 2014;10.1111/bph.12721

75 Ohkubo T, Yamazaki J: T-type voltage-activated calcium channel Cav3.1, but not Cav3.2, is involved in the inhibition of proliferation and apoptosis in MCF-7 human breast cancer cells. Int J Oncol 2012;41:267-275. 